\title{
Principal component analysis of the effects of flooding on food security in agrarian communities of south eastern Nigeria
}

\begin{abstract}
The study focused on eight (8) agrarian communities that are vulnerable to flooding in the south eastern region of Nigeria known for its comparative advantage in the production of yam, sweet potatoes and cassava which are also staples. The negative effects of flooding on food security in the study area were measured on a likert scale and the calculated Cronbach's alpha reliability coefficient of 0.8 shows a relatively high consistency of all measured items. However, ten (10) significant negative effects of flooding on food security were analysed and Principal Component Analysis (PCA) extracted three components of eigen values $>1$ explaining $68.02 \%$ of the total variance, thus summarizing these negative effects of flooding on food security in three (3) aspects namely; food supply and distribution; household income and investment; and farm labour and facilities.
\end{abstract}

Keywords: flooding, food security, south eastern Nigeria, Principal Component Analysis, vulnerability
Volume 2 Issue 2 - 2018

\author{
Akukwe Thecla I,' Krhoda George O, ${ }^{2}$ \\ Oluoko-Odingo Alice $\mathrm{A}^{2}$ \\ 'Department of Geography, University of Nigeria, Nigeria \\ ${ }^{2}$ Department of Geography and Environmental Studies, \\ University of Nairobi, Kenya
}

Correspondence: Akukwe Thecla I, Department of Geography, University of Nigeria, Nigeria, Email thecla.akukwe@unn.edu.ng

Received: March 26, 2018 | Published: April 10, 2018

\section{Introduction}

Flooding is a general condition of partial or complete inundation of normally dry areas from overflow of inland or tidal waters or from unusual and rapid accumulation of runoff. ${ }^{1}$ Floods as noted by Odufuwa et $\mathrm{al}^{2}{ }^{2}$ are the most frequent disaster and widespread natural hazards of the world and UN-Water ${ }^{3}$ noted that, floods have caused $84 \%$ disaster deaths in the world with an average of 20,000 deaths per year, which makes only a few countries immune to floods. The growing flood scenarios in different parts of the world have resulted in loss of human lives, displacement of people, loss in properties and general damage to the environment and Madzwamuse, ${ }^{4}$ Speranza, ${ }^{5} \&$ Nzeadibe et al., ${ }^{6}$ have noted developing countries to be the most vulnerable to these impacts due to their low adaptive capacity. Consequently, Nigerian flood damage records show that many people have lost their lives to flooding while hundreds of thousands have been rendered homeless and properties worth billions of Naira have been destroyed as a result of devastating floods across Nigeria. ${ }^{1,7-9}$ These floods usually occur in three forms in Nigeria, viz; urban flooding, coastal flooding and river flooding and urban flooding. ${ }^{10}$ The occurrence of floods in Nigeria is not a recent phenomenon, ${ }^{11-16}$ Incidences of destructive floods have been recorded in different parts of Nigeria, for instance, the floods that occurred in Ibadan $(1985,1987,1990,2011)$, Osogbo (1992, 1996, 2002), Yobe (2000), Akure (1996, 2000, 2002, 2004 and 2006), Makurdi in 2008, Sokoto in 2010, Ogbaru and Oguta in 2012. In addition, the coastal cities of Lagos, Yenegoa, Calabar, Uyo, Port Harcourt and Warri frequently experience floods. ${ }^{16-19}$ Of all these floods the most devastating had been noted to be the August-October 2012 in Nigeria which pushed rivers over their banks and submerged hundreds of kilometres of urban and rural lands ${ }^{20}$ with an estimate of over 7,705,378 Nigerians affected by the floods leaving 2,157,419 persons internally displaced (IDPs). Moreover, over $90 \%$ of the 36 States of the country were affected between July and October, 2012 with 363 deaths and more than 618,000 damaged houses. ${ }^{21}$ It was also noted to have caused massive destruction of farmlands which resulted to food insecurity in parts of the country as significant proportion of areas (including the south eastern region) that produce the three main tuber food crops in Nigeria (namely yam, cassava and sweet potato), were affected by the floods. ${ }^{22,23}$ Food security, according to FAO. ${ }^{24,25}$ exists when all people, at all times, have physical and economic access to sufficient, safe and nutritious food that meets their dietary needs and food preferences for an active and healthy life. Food security in the above context consists of four dimensions viz; food availability, accessibility, utilization and stability. Food accessibility is a measure of the ability to obtain/secure food, usually determined by affordability of food and money spent on food while food availability is determined by sufficiency of food that are produced, stored, processed, distributed and exchanged. In addition, food utilization refers to the essential nutrients secured from the food consumed including access to potable water and safety of food and stability emphasizes the importance of having to reduce the risk of adverse effects on the other three dimensions: food availability, food accessibility or food utilization over time; it deals with the phrase "at all times" in the food security definition by FAO ${ }^{25}$ A state of food insecurity would occur once any of the food security dimensions is truncated by flooding, drought or any environmental change, hence, there exist a relationship between flooding and food (in)security. Since Ramakrishna et al., ${ }^{26} \&$ Zakari et al. ${ }^{27}$ found flooding to have significant negative impacts on food security in Khammam (India) and Niger Republic respectively, there was need to assess the aspects in which flooding affect food security in the agrarian and flood vulnerable communities in the south eastern region of Nigeria. Extensive works had been carried out on the effects of flooding on health and environment in Nigeria ranging from destruction of roads and other infrastructure, stream pollution, coastal erosion, destruction of farms to loss of lives and property. $2,8,9,15,28-32$. Yet, there is dearth of literature on the extent of negative effects of flooding of food security directly or indirectly in the study area. Thus, this study examined the negative effects of flooding on food security both directly and indirectly as well as summarized them under key 
aspects as shown by the underlying dimensions extracted from the results of the Principal Component Analysis (PCA).

\section{Study area}

\section{Location}

The study area, Southeastern Nigeria, comprises the five Igbo speaking States of Abia, Anambra, Ebonyi, Enugu and Imo. These States constitute one of the six geo-political zones in Nigeria. It is located between latitudes $4^{\circ} 20^{\prime}$ to $7^{\circ} 10^{\prime}$ north of the equator and longitudes $6^{\circ} 35^{\prime}$ to $8^{\circ} 25^{\prime}$ east of the Greenwich Meridian with a land size of about $28,983 \mathrm{~km}^{2}$. The region is bounded to the north by Benue and Kogi states, to the south by Rivers state, to the east by Cross River state and to the west by Delta state (Figure 1). Anambra and Imo States had been selected for this study since they were the severely affected States in the region by the 2012 floods on which this study is predicated on. Anambra State is located between latitudes $5^{\circ} 40^{\prime}$ and $6^{\circ} 46^{\prime}$ north of the equator and longitudes $6^{\circ} 35^{\prime}$ and $7^{\circ} 21^{\prime}$ east of the Greenwich meridian with a spatial extent of about $4,816 \mathrm{~km}^{2}$. Imo State lies between latitude $5^{\circ} 10^{\prime} \mathrm{N}$ to $5^{\circ} 25^{\prime} \mathrm{N}$ and longitude $6^{\circ} 35^{\prime} \mathrm{E}$ to $7^{\circ} 23^{\prime} \mathrm{E}$ of the Greenwich meridian with a total land area of about $5,183 \mathrm{sqkm} .{ }^{33}$

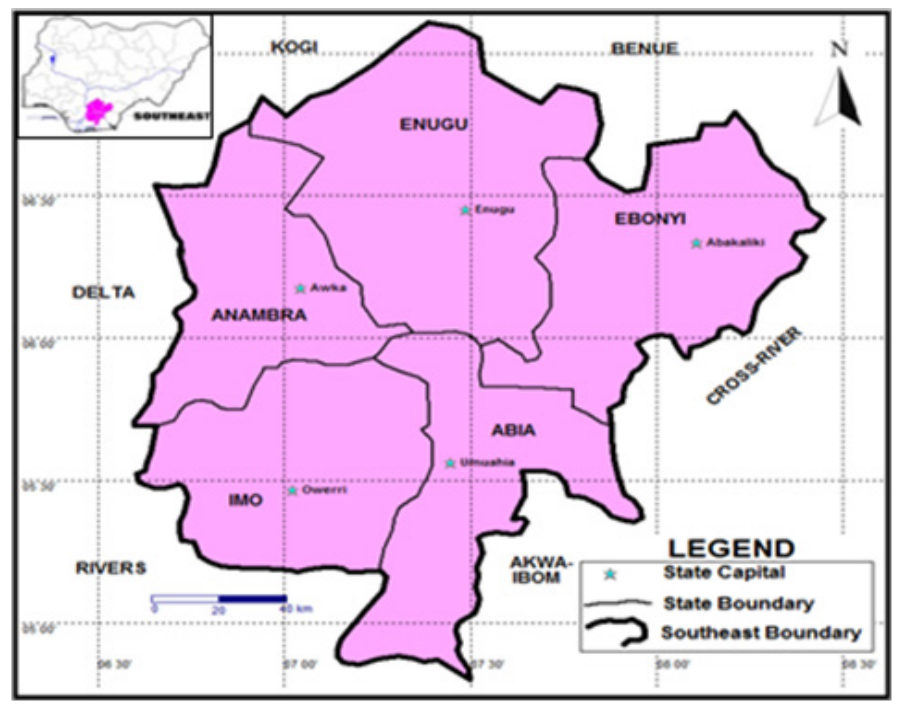

Figure I Map of the Study Area.

Source: GIS Lab., Department of Geography, University of Nigeria, Nsukka, 2016

\section{Climate}

Southeastern Nigeria lies within tropical wet-and-dry climate or Aw climate based on Koppen's climate classification. It usually experiences an average of eight months of rainfall and four months of dry season. The two major seasons experienced in this region are; the rainy season (March to October) and the dry season (November to February). Heaviest rainfall usually occurs in July and September while December records the driest month while the month of March records the hottest weather. Mean annual rainfall ranges from $1800 \mathrm{~mm}$ to $2000 \mathrm{~mm}$. It experiences high temperatures all year round with an average value of $27^{\circ} \mathrm{C}$ while the average relative humidity ranges between $60-70 \%$ and $80-90 \%$ in January and July respectively. ${ }^{34-38}$ Floods in south eastern Nigeria, are greatly influence by the rainfall pattern, and are usually experienced between July and October which is also the harvest season for most crops.

\section{Population}

Anambra State and Imo State had a population of 4,177,828 (with 2,117,984 male and 2,059,844 female) and 3,927,563 (with 1,976,471 male and 1,951,092 female) persons respectively according to the 2006 population census figures. The population of the four selected Local Government Areas (LGAs) are Anambra East - 152,149 persons; Ogbaru - 223,317 persons; Oguta - 142,340 persons and Ohaji/ Egbema - 182,891 persons. ${ }^{33}$ The population figures were projected into 2016 and the figure for Anambra East LGA was 205,401 persons; Ogbaru - 301,478 persons; Oguta - 192,159 persons and Ohaji/ Egbema - 246,903 persons. These projected population figures were calculated using the equation below;

$$
P_{2}=P_{1}(1+r)^{n}(1)
$$

Where; $\mathrm{P}_{2}$ is the projected population;

$\mathrm{P}_{1}$ is the known population (2006 in this case);

$\mathrm{R}$ is the rate of natural increase, $2.8 \%$ as noted by the United Nations, ${ }^{39}$

$\mathrm{n}$ is the number of years between $\mathrm{P}_{1}$ and $\mathrm{P}_{2}$ (interval) and its 11 years in our case.

\section{Methodology}

\section{Sample size and sampling method}

The study was carried out in two (2) agrarian Nigerian Southeastern States namely; Imo and Anambra States which are the most vulnerable States to flooding as they were the only two States affected in the region by the 2012 floods termed the most devastating floods in Nigeria. ${ }^{21}$ In Imo State, only two Local Government Areas (LGAs) namely; Oguta and Ohaji/Egbema LGAs were affected by the 2012 floods, so, two flood vulnerable but easily accessible LGAs (Anambra East and Ogbaru) were purposively selected in Anambra State for equal representation of the two States. These four LGAs viz; Oguta and Ohaji/Egbema LGAs (in Imo State); Anambra East and Ogbaru LGAs (in Anambra State) were sampled because they met the criteria of consisting of agrarian communities that are very vulnerable to floods as well as being accessible. The sample size was determined using Yamane ${ }^{40} \&$ Israel $^{41}$ equation as given below;

$$
n=N / 1+N\left(e^{2}\right)
$$

Where;

$\mathrm{n}$ is the sample size

$\mathrm{N}$ is the population of Anambra East, Ogbaru, Oguta and Ohaji/ Egbema LGAs e - is the level of precision/sampling error i.e. 0.05 (at $+/-5 \%$ level of precision)

$n=(205,401+301,478+192,159+246,903) /\left(1+(205,401+301,478+192,159+246,903)(0.05)^{2}\right)$ $\mathrm{n}=400$ households

A multi-stage purposive sampling technique was employed to establish the sampling frame and two (2) communities (one being the LGA headquarters) was purposively selected based on the criteria used in selecting the LGAs, giving a total of four (4) communities for 
each State and eight (8) communities for the two (2) States (Figure 2). In addition, stratified sampling method was used to determine the number of households sampled in each LGA and community and random sampling method was employed in administering the
400 copies of questionnaire. The study was carried out in 2016-2017 and was predicated on the devastating 2012 floods. Though flooding might have positive effects on food security, this study concentrated on the negative effects influenced by observation in the study area.

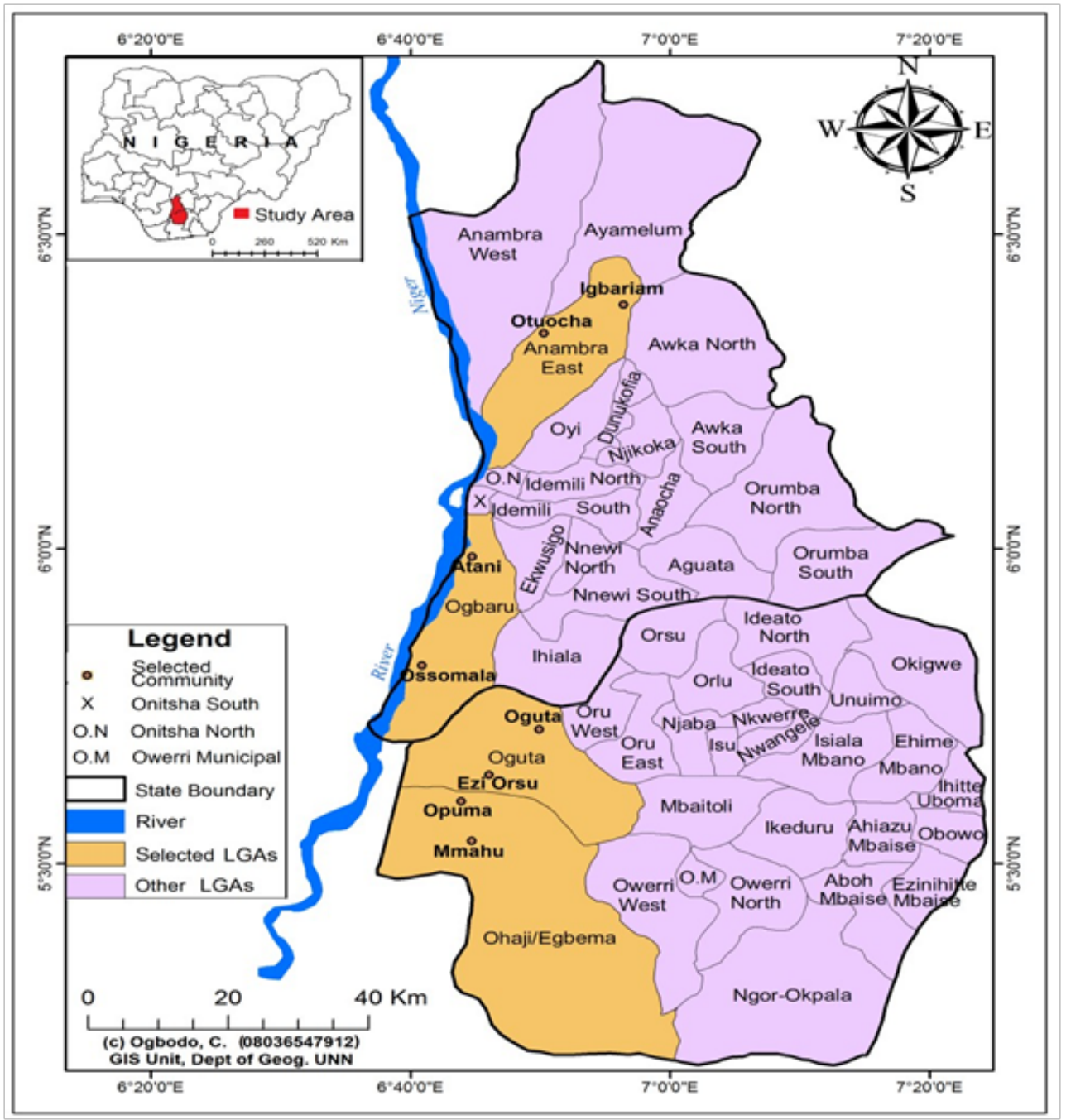

Figure 2 Map of the study area showing the sampled LGAs/Communities.

Source: GIS Lab., Department of Geography, University of Nigeria, Nsukka, 2016

\section{Data sources/collection}

The study was questionnaire-based and 400 (derived from the sample size) copies of questionnaire were administered. Two Focus Group Discussions (FGDs) and Key Informant Interviews (KIIs) were conducted in each LGA and they served as validation tools to the researchers' observations as well as to the responses of the respondents. The respondents consisted of households' heads (mostly farmers) whose households had experienced flooding and its effects in one form or the other since the study was carried out in agrarian communities.

\section{Data analysis}

The negative effects of flooding on food security were measured on a 5-point likert scale with a value of 1 and 5 as the lowest and highest respectively. Simple percentages were used to explain the responses on the likert scale.

The coefficient of reliability (consistency) of the items (variables in this case, the identified negative effects) was measured using the Cronbach's alpha reliability statistic with an acceptable reliability value of $\geq 0.70$. The reliability coefficient of $\geq 0.70$ is a prerequisite for running mean scores.Furthermore, mean score was used to determine the significance of the negative effects of flooding on food security with a mean score of $>3.0$ considered significant.

Finally, Principal Component Analysis (PCA) was used to determine the major areas that flooding affects food security. PCA is a 
technique for extracting from a set of variables those few orthogonal linear combinations of variables that most successfully capture the common information. ${ }^{42}$

\section{Discussion of results}

\section{Socio-economic Characteristics of respondents}

The socio-economic characteristics of the respondents are shown in Table 1. Majority of the respondents were households' heads who dependent on agriculture as a major source of income/livelihoods. This implies that majority of the households were highly vulnerable to both flooding and food insecurity as their major source of livelihoods was climate-related. The sampled households comprised $43.8 \%$ female and $56.2 \%$ male who had been affected by flooding. The table illustrates an age mix with majority of the household heads being between the ages of 40 and 49 years $(25.8 \%)$ as well as 60 and 69 years (25\%). A small proportion was between 20 and 29 years $(6.3 \%)$ while the lowest percentage (1.2\%) accounted for respondents who were 70 years and above. In terms of marital status, a large proportion (64.5\%) of the respondents was married with about a fifth (19.8\%) of them being widowed while the remaining $15.7 \%$ were either single, divorced or separated. The years of stay of the respondents in their various had been likened to their years of farming experience. With $78.5 \%$ accounting for respondents who had stayed above 20 years in their communities, then the extent of the negative effects of flooding on food security as reported by the respondents must have been from their experiences.

Table I Socio-economic characteristics of respondents

\begin{tabular}{|c|c|c|}
\hline Characteristic & Component & $\begin{array}{l}\text { Frequency } \\
\text { (percentage) }\end{array}$ \\
\hline \multirow[t]{3}{*}{ Sex } & Male & 225 (56.2\%) \\
\hline & Female & I 75 (43.8\%) \\
\hline & Total & $400(100 \%)$ \\
\hline \multirow[t]{7}{*}{ Age } & 20-29 Years & $25(6.3 \%)$ \\
\hline & 30-39 Years & 83 (20.7\%) \\
\hline & 40-49 Years & $103(25.8 \%)$ \\
\hline & $50-59$ years & $84(21.0 \%)$ \\
\hline & 60-69 Years & $100(25.0 \%)$ \\
\hline & 70 Years \& above & 5 (1.2\%) \\
\hline & Total & 400 (100\%) \\
\hline \multirow[t]{5}{*}{$\begin{array}{l}\text { Primary sources of } \\
\text { livelihoods }\end{array}$} & Farming & $368(92.0 \%)$ \\
\hline & Fishing & $3(0.8 \%)$ \\
\hline & Trading/Business & $3(0.8 \%)$ \\
\hline & Civil servant & $26(6.5 \%)$ \\
\hline & Total & 400 (100\%) \\
\hline \multirow[t]{4}{*}{ Marital status } & Single & 31 (7.8\%) \\
\hline & Married & $258(64.5 \%)$ \\
\hline & Divorced & $5(1.3 \%)$ \\
\hline & Separated & 27 (6.7\%) \\
\hline
\end{tabular}
security

\begin{tabular}{llll}
\hline $\begin{array}{l}\text { Does flooding have } \\
\text { negative effect on } \\
\text { food security? }\end{array}$ & Frequency & Percent & $\begin{array}{l}\text { Cumulative } \\
\text { percent }\end{array}$ \\
\hline Yes & 397 & 99.3 & 99.3 \\
No & 3 & 0.7 & 100 \\
Total & 400 & 100 & \\
\hline
\end{tabular}

Source: Researcher's Computation, 2017

Flooding was found to have influenced food insecurity as majority $(99.3 \%)$ of the respondents adduced (Table 2). This implies that virtually all the households had experienced one or more negative effects of flooding on food security as shown in Table 3 and since the sampled households were agrarian, the effects were devastating.

The analysed negative effects were; flooding reduces crop harvest; decreases farm income derived from crop sales; destroys road; destroys food/ farm storage facilities; reduces labour demand; pollutes streams; reduces the number of times food is consumed; affects the quality of food eaten; increases food items prices and it affects the quantity of food eaten (Table 3). Some of the identified negative effects of flooding on food security are indirect, for instance, roads are important in the transportation of agricultural products from farms to market and when these roads are destroyed by flooding, food security is affected indirectly which is in line with the findings of Etuonovbe, Adewuyi, ${ }^{28} \&$ Duru et al., ${ }^{30}$ In the same vein, when crop failure occurs as a result of flooding, food availability is affected with an associated reduction in meal frequency and quantities. Flooding was found to reduce crop/fish pond harvest and farm income, thereby affecting 
household food security in the study area especially as majority of the households are agrarian (depending on agriculture for their food and income). This agrees with the findings of Otomofa et al., ${ }^{31}$ where $66 \%$ of their respondents strongly agreed that flooding caused loss of fish stock in their ponds. In addition, this is somewhat related to the findings of Ikani ${ }^{32}$ who noted that flooding caused loss of farm crops in Gwagwalada Area Council in Nigeria, thereby indirectly affecting food security of households. Similarly, food prices are usually low during harvest periods, but flooding alters this seasonal pattern by causing a rise in food prices as a result of crop failure, corroborating the findings of Otomofa et al., ${ }^{31}$ and flood events occur mostly between July and October, the harvest season for staples like yam in south eastern Nigeria. Floods also upset the balance between labour supply and demand because after flood events, there is often an abrupt rise in labour supply (especially as households take up casual labour to help themselves after flood-induced poor harvest) with an associated decrease in labour demand due to the reduced number of households that required the labour.

Table 3 Negative Effects of flooding on food security

\begin{tabular}{|c|c|c|c|c|c|}
\hline \multirow{2}{*}{$\begin{array}{l}\text { Negative effect of flooding on food } \\
\text { security }\end{array}$} & \multicolumn{5}{|c|}{ Extent of effect } \\
\hline & $\mathbf{I}$ & 2 & 3 & 4 & 5 \\
\hline $\begin{array}{l}\text { Reduces crop/fish pond } \\
\text { harvest }\end{array}$ & $0(0.0 \%)$ & $5(1.3 \%)$ & $9(2.3 \%)$ & $223(55.7 \%)$ & $163(40.7 \%)$ \\
\hline $\begin{array}{l}\text { Decreases farm income } \\
\text { derived from crop sales }\end{array}$ & $0(0.0 \%)$ & $10(2.5 \%)$ & $16(4.0 \%)$ & $222(55.5 \%)$ & $152(38.0 \%)$ \\
\hline Destroys road & $0(0.0 \%)$ & $4 \mathrm{I}(10.3 \%)$ & $72(18.0 \%)$ & $224(56.0 \%)$ & $63(15.7 \%)$ \\
\hline $\begin{array}{l}\text { Destroy food/ farm } \\
\text { storage facilities }\end{array}$ & $0(0.0 \%)$ & $20(5.0 \%)$ & $117(29.3 \%)$ & $174(43.5 \%)$ & $89(22.2 \%)$ \\
\hline Reduces labour demand & $13(3.3 \%)$ & $96(24.0 \%)$ & $103(25.7 \%)$ & $\mathrm{I} 0 \mathrm{I}(25.3 \%)$ & $87(21.7 \%)$ \\
\hline Pollutes streams & $0(0.0 \%)$ & $10(2.5 \%)$ & $19(4.7 \%)$ & $161(40.3 \%)$ & $210(52.5 \%)$ \\
\hline $\begin{array}{l}\text { Reduces the number of } \\
\text { times food is consumed }\end{array}$ & $0(0.0 \%)$ & $67(16.7 \%)$ & $110(27.5 \%)$ & $187(46.8 \%)$ & $36(9.0 \%)$ \\
\hline $\begin{array}{l}\text { Affects the quality of } \\
\text { food eaten }\end{array}$ & $24(6.0 \%)$ & $74(18.5 \%)$ & $106(26.5 \%)$ & $148(37.0 \%)$ & $48(12.0 \%)$ \\
\hline $\begin{array}{l}\text { Affects the quantity of } \\
\text { food eaten }\end{array}$ & $0(0.0 \%)$ & $64(16.0 \%)$ & $124(3 \mid .0 \%)$ & $190(47.5 \%)$ & $22(5.5 \%)$ \\
\hline $\begin{array}{l}\text { Increases food items } \\
\text { prices }\end{array}$ & $0(0.0 \%)$ & $2(0.5 \%)$ & $79(19.7 \%)$ & $254(63.5 \%)$ & $65(16.3 \%)$ \\
\hline
\end{tabular}

A 5-point scale with I, To no extent; 2 , To little extent; 3 , To a moderate extent; 4 , To a great extent; 5 , To a very great extent

Table 3 reveals that the ten (10) identified negative effects of flooding on food security were to a great extent with the largest proportions of households indicating that it increases food prices (63.5\%), destroys roads (56\%), reduces crop harvest $(55.7 \%)$ and reduces farm income derived from crop sales $(55.5 \%)$. This illustrates that food availability and food accessibility dimensions of food security had been severely affected in times of flooding in the study area and these findings are in agreement with the findings of Devereux.$^{43}$ In the same vein, a larger proportion of households indicated flooding to affect the quantity of food eaten $(47.5 \%)$, reduce the number of times food is consumed (46.8\%), destroy food/ farm storage facilities (43.5\%) which is in consonance with the findings of Ikani (2016), pollute streams $(40.3 \%)$, affect the quality of food eaten $(37 \%)$ and reduce labour demand $(25.3 \%)$ to a great extent. This implies that food utilization as well as the stability dimensions of food security is adversely affected by flooding. However, flooding was found to have caused streams pollution a great deal as a high percentage of households $(52.5 \%)$ had responded that the effect was to a very great extent which corroborates the findings of Odufuwa et al., ${ }^{2}$ This also corresponds with the findings of Ajaero et al., ${ }^{29}$ where $33.3 \%$ and
$50 \%$ of respondents in Ogbaru and Anambra East LGAs in their study respectively indicated that flooding caused stream pollution.

Generally, the study has shown flooding to have serious negative effects on food security as most of the households indicated the effects to be in a great extent (Table 3). Furthermore, with a Cronbach alpha coefficient of 0.8 showing a relatively high internal consistency of the measured item on the likert scale because it is $>0.70$, mean score was adopted to show if the negative effects of flooding on food security was significant or not. The effects were analysed on a Likert scale with an expected mean of 3.0 and the calculated mean score of the negative effects was 3.82. Since the calculated mean score for the negative effects of flooding is greater than 3.0 , it could be concluded that flooding has significant negative effects on food security in the Southeastern region of Nigeria.

\section{Principal component analysis of the negative effects of flooding on food security}

The Principal Component Analysis (PCA) was employed to reduce and group the ten (10) analyzed negative effects of flooding 
on food security. PCA is a technique for extracting from a set of variables those few orthogonal linear combinations of variables that most successfully capture the common information by converting these interrelated variables into a new set of uncorrelated variables called the principal components. ${ }^{42,44,45}$ PCA does data reduction by combining a large number of indicators into fewer similar groups, each group defining the underlying dimension in the contributing variables forming the group. ${ }^{42}$ Eigen values are simply the coefficients attached to eigenvectors ranked in descending order of their eigen values to arrive at the principal components in order of significance.
This implies that they are the measure of the data's covariance. ${ }^{46}$ PCA was run on the negative effects of flooding on food security to determine the underlying dimensions (summary). The PCA extracted three (3) components with Eigen values greater than 1, explaining $68.02 \%$ of the total variance in the data set. The first, second and third components explained $33.65 \%, 18.23 \%$ and $10.22 \%$ respectively of all variations (Table 4 ). This implies the PCA explaineded $68.02 \%$ of the negative effects of flooding on food security summarized as three (3) underlying dimensions coined from the negative effects loaded significantly in the 3 extracted components (Table 5).

Table 4 Total Variance Explained of the PCA

\begin{tabular}{|c|c|c|c|c|c|c|c|c|c|}
\hline \multirow[t]{2}{*}{ Component } & \multicolumn{3}{|c|}{ Initial eigen values } & \multicolumn{3}{|c|}{ Extraction sums of squared loadings } & \multicolumn{3}{|c|}{ Rotation sums of squared loadings } \\
\hline & Total & $\begin{array}{l}\% \text { of } \\
\text { variance }\end{array}$ & $\begin{array}{l}\text { Cumulative } \\
\%\end{array}$ & Total & $\begin{array}{l}\% \text { of } \\
\text { variance }\end{array}$ & $\begin{array}{l}\text { Cumulative } \\
\%\end{array}$ & Total & $\begin{array}{l}\% \text { of } \\
\text { variance }\end{array}$ & $\begin{array}{l}\text { Cumulative } \\
\%\end{array}$ \\
\hline I & 3.913 & 39.126 & 39.126 & 3.913 & 39.126 & 39.126 & 3.365 & 33.652 & 33.652 \\
\hline 2 & 1.823 & 18.232 & 57.358 & 1.823 & 18.232 & 57.358 & 1.819 & 18.186 & 51.838 \\
\hline 3 & 1.066 & 10.663 & 68.021 & 1.066 & 10.663 & 68.021 & 1.618 & 16.183 & 68.021 \\
\hline 4 & 0.811 & 8.11 & 76.131 & & & & & & \\
\hline 5 & 0.726 & 7.258 & 83.389 & & & & & & \\
\hline 6 & 0.514 & 5.141 & 88.53 & & & & & & \\
\hline 7 & 0.459 & 4.588 & 93.118 & & & & & & \\
\hline 8 & 0.309 & 3.091 & 96.209 & & & & & & \\
\hline 9 & 0.221 & 2.207 & 98.416 & & & & & & \\
\hline 10 & 0.158 & 1.584 & 100 & & & & & & \\
\hline
\end{tabular}

Extraction method: Principal Component Analysis.

Table 5 Rotated Component Matrix ${ }^{a}$ of the PCA

\begin{tabular}{|c|c|c|c|}
\hline \multirow{2}{*}{ Direct and indirect effects of flood on food security } & \multicolumn{3}{|c|}{ Component } \\
\hline & $\mathbf{I}$ & 2 & 3 \\
\hline Reduces crop harvest $(\mathrm{XI})$ & 0.095 & $0.908 *$ & 0.027 \\
\hline Decreases farm income derived from crop sales $(X 2)$ & 0.009 & $0.899 *$ & 0.166 \\
\hline Destroys road (X3) & $0.570 *$ & 0.243 & 0.285 \\
\hline Destroy food/ farm storage facilities (X4) & 0.066 & 0.236 & $0.811 *$ \\
\hline Reduces labour demand (X5) & 0.215 & -0.001 & $0.777^{*}$ \\
\hline Pollutes streams (X6) & 0.445 & -0.022 & 0.369 \\
\hline Reduces the number of times food is consumed $(X 7)$ & $0.895^{*}$ & 0.008 & -0.012 \\
\hline Affects the quality of food eaten (X8) & $0.883^{*}$ & -0.031 & 0.155 \\
\hline Affects the quantity of food eaten (X9) & $0.911 *$ & -0.012 & 0.103 \\
\hline Increases food items prices $(X \mid 0)$ & $0.610 *$ & 0.263 & 0.276 \\
\hline
\end{tabular}

Extraction method: Principal Component Analysis; Rotation method:Varimax with Kaiser Normalization.

*The significant loadings exceeding $+/-0.60$ 


\section{Interpretation of the components}

\section{Component one}

With an Eigen value of 3.91 (Table 4), it loaded positively and significantly on X3- destroys road (.57), X7- reduces meal frequency (.895); X8- affects the quality of food eaten (.883), X9- affects the quantity of food eaten (.911) and X10- increases food items prices (.61) (Table 5). The underlying dimension is thus termed, food supply and distribution considering the variables (X3, X7, X8 and $\mathrm{X} 10$ ) with significant loadings. The positive relationship (shown by the component values) gives credence to the fact that flooding did actually affect food security negatively in the study area.

\section{Component two}

It has an Eigen value of 1.82 (Table 4), with positive and significant loadings on X1- reduces crop harvest (.908) and X2- decreases farm income derived from crop sales (.899) shown in Table 5 and has been termed influence on household income and investment. Respectively, $96.4 \%$ and $93.5 \%$ households reported flooding to influence X1 and $\mathrm{X} 2$ to a great and very great extent collectively (Table 3 ).

\section{Component three}

Eigen value of 10.66 (Table 4) was reported for this component which was positively and significantly loaded on X4- destroy food/ farm storage facilities (.811) and X5- reduces labour demand (.777) shown in Table 5. Households that reported flooding to influence X4 and X5 to a great and very great extent were $65.7 \%$ and $47 \%$ correspondingly (Table 3). The underlying dimension for this component could be termed farm labour and facilities. However, the positive loadings on all the significant variables, further buttress the point that flooding has negative effect on food security in the study area. For instance, as flooding increases, there is also an increase in crop harvest reduction as depicted by the significant positive value (.908) on X2- reduces crop harvest under component 2.

Conclusively, the PCA explained $68.02 \%$ of the variance in the negative effects on food security by flooding in south eastern Nigeria and was used to reduce the ten (10) identified negative effects of flooding on food security to three (3) underlying dimensions that flooding affect namely;

i. Food supply and distribution;

ii. Household income and investment;

iii. Farm labour and facilities.

\section{Conclusion}

Flooding was found to cause a negative shift in food security by reducing crop harvest, affecting income, destroying roads, reducing labour demand, destroying food/farm storage facilities, causing stream pollution, increasing food prices, affecting meal frequency, affecting quality and quantity of food eaten among others in Anambra and Imo States. The study has shown that flooding has negative effects on food security in various aspects and these effects are significant with a mean score of 3.82 on a 5-point likert scale in the study area. The PCA results extracted three components and flooding was summarized to affect three major aspects viz; food supply and distribution; household income and investment; and farm labour and facilities as regards food security. However, the sampled States (Anambra and Imo) in the south eastern region of Nigeria are in the Niger Delta region of Nigeria that is known for its vulnerability to flooding due to its nearness to the River Niger, therefore, sustainable flood management strategies are recommended to cushion the effects of flooding on households' food security in the region.

\section{Acknowledgment}

None.

\section{Conflict of interest}

The authors declare no conflict of interest.

\section{References}

1. Jeb DN, Aggarwal SP. Flood inundation hazard modelling of the River Kaduna using remote sensing and Geographic Information Systems. Journal of Applied Sciences Research. 2008;4(12):1822-1833.

2. Odufuwa BO, Adedeji OH, Oladesu JO, et al. Floods of Fury in Nigerian Cities. Journal of Sustainable Development. 2012;5(7).

3. UN-Water. Cities coping with water uncertainties. Media Brief, UNWater Decade Programme on Advocacy and Communication. 2011.

4. Madzwamuse M. Climate Change Vulnerability and Adaptation Preparedness in South Africa. Cape Town: Heinrich Böll Foundation; 2010.

5. Speranza CI. Resilient Adaptation to Climate Change in African Agriculture. Bonn: Deutsches Institut fur Entwicklungspolitik (D.I.E); 2010.

6. Nzeadibe TC, Egbule CL, Chukwuone N, et al. Farmers' Perception of Climate Change Governance and Adaptation Constraints in Niger Delta Region of Nigeria. Nairobi: African Technology Policy Studies Network; 2011.

7. Opalana T. Experts Proffer Solutions to Lagos Flooding. Nigerian Tribune. 2005. p. 24.

8. Etuonovbe AK. Devastating Effect of Flooding in Nigeria. FIG Working Week 2011: Bridging the Gap between Cultures, Marrakech, Morocco; 2011.

9. Olorunfemi FB. Managing flood disasters under a changing climate: Lessons from Nigeria and South Africa. Paper presented at NISER Research Seminar Series, Ibadan. 2011.

10. Orok HI. A GIS-Based Flood Risk Mapping of Kano City, Nigeria. School of Environmental Sciences, University of East Anglia, Norwich; 2011.

11. Ayoade JO. A note on the recent flood in Ibadan. Savanna. 1979;8(1):6265.

12. Ayoade JO, Akintola FO. Public perception of flood hazard in two Nigerian cities. Environ Int. 1980;4(4):277-280.

13. Olaniran OJ. Flood generating mechanisms at Ilorin, Nigeria. Geo Journal. 1983;7(3):271-277.

14. Ologunorisa TE, Terso T. The changing rainfall pattern and its implications for flood frequency in Makurdi, Northern Nigeria. Journal of Applied Sciences and Environ Management. 2006;10(3):97-102.

15. Adeloye A. Rustum R. Lagos (Nigeria) flooding and influence of urban planning. Journal of Urban Design and Planning (ICE). 2011;164(3):175-187. 
16. Akukwe TI, Ogbodo C. Spatial analysis of vulnerability to flooding in Port Harcourt metropolis, Nigeria. SAGE Open. 2015;5(1):1-19.

17. Mordi R. The Tsunami in the making. The Tell. 2011. p. 54-63.

18. Amaize E. Flood displaces 50 Villagers in Delta State. Vanguard. 2011;9.

19. Olajuyigbe AE, Rotowa OO, Durojaye E. An Assessment of Flood Hazard in Nigeria: The Case of Mile 12, Lagos. Mediterranean Journal of Social Sciences. 2012;3(2):366-377.

20. Ojigi ML, Abdulkadir FI, Aderoju MO. Geospatial Mapping and Analysis of the 2012 Flood Disaster in Central Parts of Nigeria. Paper presented at the $8^{\text {th }}$ National GIS Symposium, Dammam, Saudi Arabia. 2013.

21. OCHA. (United Nations Office for the Coordination of Humanitarian Affairs). Nigeria: Floods Situation Report No. 1 (as of 06 November 2012). 2012. p. 1-6.

22. FEWSNET. Third quarter. Famine Early Warning Systems Network 2012.

23. Famine Early Warning Systems Network (FEWSNET). Nigeria Food Security Update, "Food insecurity increases in Regions affected by flooding and conflict". FEWSNET; 2013. p. 1-2.

24. FAO. Rome Declaration on World Food Security and World Food Summit Plan of Action. Rome: FAO Document Repository; 1996.

25. FAO. Food Security Concepts and Frameworks: Food Security Information for Action. FAO; 2008. p. 1-14.

26. Ramakrishna G, Gaddam SR, Daisy I. Impact of Floods on Food Security and Livelihoods of IDP tribal households: The case of Khammam region of India. International Journal of Development and Economics Sustainability. 2014;2(1):11-24.

27. Zakari S, Ying L, Song B. Factors Influencing Household Food Security in West Africa: The Case of Southern Niger. Sustainability. 2014;6(3):1191-1202.

28. Adewuyi TO, Olofin EA. Spatio-Temporal Analysis of Flood Incidence in Nigeria and Its Implication for Land Degradation and Food Security. Journal of Agricultural Science. 2014;6(2):150-159.

29. Ajaero CK, Mozie AT. Socio-demographic differentials in vulnerability to flood disasters in rural Southeastern Nigeria. A paper presented at the International Seminar on Demographic Differential Vulnerability to Natural Disasters in the Context of Climate Change Adaptation, Kao Lak, Thailand. 2014

30. Duru PN, Chibo CN. Flooding in Imo State Nigeria: The SocioEconomic Implication for Sustainable Development. Humanities and Social Sciences Letters. 2014;2(3):129-140.

31. Otomofa JO, Okafor BN, Obienusi EA. Evaluation of the Impacts of Flooding On Socio-Economic Activities in Oleh, Isoko South Local Government Area, Delta State. Journal of Environment and Earth Science. 2015;5(18):155-171.
32. Ikani DI. An Impact Assessment of Flooding on Food Security among Rural Farmers in Dagiri Community of Gwagwalada Area Council, Abuja. Nigeria. Agricultural Development. 2016;1(1):6-13.

33. National Population Commission. 2006 Population and Housing Census: Population Distribution by Sex, State, LGA and Senatorial District (Priority Table Volume III). Abuja: National Population Commission; 2010.

34. Monanu PC. Temperature and Sunshine. In: Ofomata, GEK, editors. Nigeria in Maps: Eastern States. Benin City: Ethiope Publishing House; 1975a. p. 16-18.

35. Monanu PC. Humidity. In: Ofomata, GEK, editors. Nigeria in Maps: Eastern States. Benin City: Ethiope Publishing House; 1975b.

36. Anyadike RNC. Climate and Vegetation. In: Ofomata GEK, editors. A Survey of the Igbo Nation. Onitsha: Africana FEP Publishers; 2002. p. $73-82$.

37. Akukwe TI. Environmental Quality and the Impact of Bureau for Environment and Sanitation in Owerri Urban Area, Imo State, Nigeria. Department of Geography, University of Nigeria, Nsukka. 2007.

38. Duru AJ. The implications of variability in rainfall over Imo state on little dry season (1975-2007). Imo State University, Owerri: Department of Geography and Environmental Management; 2008.

39. United Nations. World Population Prospects: The 2012 Revision. New York: UN. ESA/P/WP.228; 2013.

40. Yamane T. Statistics: An Introductory Analysis, $2^{\text {nd }}$ edition. New York: Harper and Row; 1967.

41. Israel GD. Sampling the Evidence of Extension Program Impact Program Evaluation and Organisational Development. Institute of Food and Agricultural Sciences (IFAS): University of Florida (PEOD-5); 1992.

42. Anyadike RNC. Statistical Methods for the Social Sciences. Ibadan Spectrum Books Limited; 2009.

43. Devereux S. The impact of droughts and floods on food security and policy options to alleviate negative effects. Agricultural Economics. 2007;37(s1):47-58.

44. Deressa T, Hassan RM, Ringler C. Measuring Ethiopian Farmers Vulnerability to Climate Change across Regional States (Discussion Paper 00806). Washington DC: International Food Policy Research Institute (IFPRI); 2008.

45. Yang L. An Application of Principal Component Analysis to Stock Portfolio Management. Department of Economics and Finance, University of Canterbury. 2015.

46. PCA. A beginner's guide to eigenvectors. Covariance and entropy. 2018. 